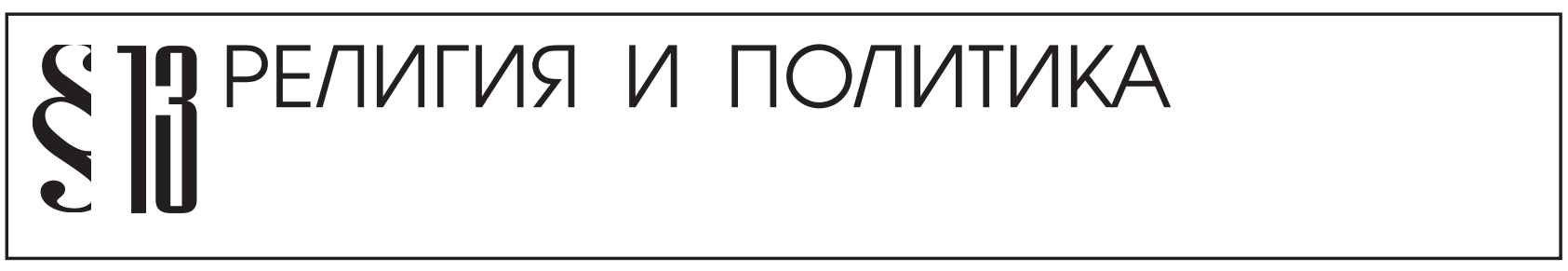

Тарасевич И.А., Зенковский А.В.

\title{
ПРОБЛЕМЫ ПРОТИВОДЕЙСТВИЯ РЕЛИГИОЗНОМУ ЭКСТРЕМИЗМУ В КОНТЕКСТЕ ОБЕСПЕЧЕНИЯ РЕЛИГИОЗНОЙ БЕЗОПАСНОСТИ: СРАВНИТЕЛЬНО-ПРАВОВОЙ АНАЛИЗ ЗАКОНОДАТЕЛЬСТВА РОССИИ И РЕСПУБЛИКИ КАЗАХСТАН
}

\begin{abstract}
Аннотация: $B$ статье выдвигается идея о том, что в настоящее время проблема религиозного экстремизма особенно актуальна для двух стран - стратегических партнеров по Таможенному и Евразийскому Союзу: России и Казахстана. В связи с этим особое значение приобретает постоянный мониторинг и совериенствование нормативно-правовой базы по борьбе с религиозным экстремизмом в указанных странах.Авторы приводят краткий сравнительный правовой анализ законодательства, которое призвано обеспечить религиозную безопасность России и Казахстана. В частности, сравнительному исследованию подвергаются нормы, закрепляюшие понятие религиозного экстремизма в российской и казахстанской правовых системах. Дается оценка слабых и сильных сторон соответствующего законодательства двух стран. В статье обрашается особое внимание на необходимость закрепления в российском и казахстанском законодательствах четкого определения понятия разжигания религиозной ненависти, розни или вражды, что позволит отличать такие противоправные деяния от добросовестной миссионерской и апологетической деятельности. Авторы обращают внимание на проблему прозелитизма и предлагают собственное определение такой деятельности, а также обосновьвают необходимость признания прозелитизма экстремистской деятельностью и установления за такую деятельность юридической ответственности. Особое внимание в статье обращается на то, что обеспечение религиозной безопасности является одной из ключевых задач для Казахстана и России, и именно в этой сфере необходима скорейшая выработка единых для двух стран стандартов правового регулирования. По мнению авторов статьи, сущуествует значительный потенциал по совершенствованию соответствующего законодательства двух стран-партнеров, отличающихся близостью правовых систем и менталитета населения.

Review: The author of the article assumes that the problem of religious extremism is especially important for the two countries today - strategic partners of the Customs and Eurasian Union, Russia and Kazakhstan. In this regard, the emphasis is made on constant monitoring and improvement of the legal base of countering religious extremism in the above mentioned countries. The authors of the article carry out a brief comparative law analysis of the legislation on enforcing security in Russia and Kazakhstan. In particular, they analyze laws setting forth the definition of religious extremism both in Russian and Kazakhstan legal systems. The authors also evaluate the strong and weak points of associated legislations in these two countries. They pay special attention to the fact that it is necessary to provide a more distinct definition of incitement of religious hatred, intolerance and hostility' which would allow to distinguish between these illegal actions and proper missionary and apologetic activities. The authors of the article also pay our attention to the problem of proselytism and offer their own definition of this activity as well as prove that proselytism should be regarded as extremism and legally punished. It is especially stressed out by the authors of the article that guarantees for religious security should be one of the key tasks for Kazakhstan and Russia. This is the very sphere where both countries should establish legal regulation standards as soon as possible. Based on the authors of the article, there is a significant potential to improve the current legislation in these two countries because their legal systems and national mentality are rather close to one another.
\end{abstract}




\section{Политика и общество 12 (108) 2013}

Ключевые слова: религиозный экстремизм, религиозная безопасность, Таможенный союз, религиозная нетерпимость, религия, Юриспруденция, прозелитизм, экстремистская деятельность, Россия, Казахстан

Keywords: religious extremism, religious security, Customs Union, religious intolerance, legal studies, proselytism, extremist activity, Russia, Kazakhstan.

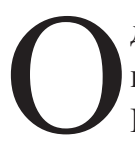
дной из угроз религиозной безопасности ${ }^{1}$ общества является религиозный экстремизм. Проблема религиозного экстремизма особенно актуальна для двух стран - стратегических партнеров по Таможенному и Евразийскому Союзу: России и Республики Казахстан. Оба наших государства являются целью религиозных экстремистов различного происхождения и направленности. Но основную угрозу и для России и для Казахстана представляют псевдоисламские религиозные направления, такие как ваххабизм.

Особую озабоченность вызывает предстоящий в 2014 году вывод международных сил безопасности (ISAF) из Афганистана. Есть все основания предполагать, что в бывшие среднеазиатские республики Советского Союза начнется массовая инфильтрация религиозных фанатиков, выдающих свою жестокость, человеконенавистничество и религиозные предрассудки за истинный ислам.

В связи с этим особое значение приобретает постоянный мониторинг и совершенствование нормативноправовой базы по борьбе с религиозным экстремизмом в России и Республике Казахстан, так как территории этих государств находятся под постоянной угрозой религиозного экстремизма, в частности, радикального ислама. Ниже мы приводим краткий сравнительный правовой анализ двух ключевых законов, которые призваны обеспечить религиозную безопасность России и Казахстана: Федерального закона Российской Федерации «О противодействии экстремистской деятельности» от 25 июля 2002 г. № 114-Ф3 (ред. от 02.07.2013) $)^{2}$ и Закона Республики Казахстан «О противодействии экстремизму» от 18 февраля 2005 года № 31-III (ред. от 13.02.2012) ${ }^{3}$. На основании данного

\footnotetext{
1 Под религиозной безопасностью мы понимаем состояние защищенности личности, общества и государства от внутренних и внешних угроз, возникающих в религиозной сфере, необходимое для укрепления основ конституционного строя того или иного государства. См.: Тарасевич И.А. Религиозная безопасность Российской Федерации. Тюмень, 2013. C. 31

${ }^{2}$ СЗ РФ. 2002. № 30. Ст. 3031.

3 «Казахстанская правда» от 26 февраля 2005 г. № 45-46 (24655-24656)
}

анализа мы сформулируем практические рекомендации для законодателей двух стран-партнеров, которые в данные момент, безусловно, находятся на передовой борьбы с религиозным экстремизмом.

Еще одним поводом нашего обращения к теме сравнительного правового анализа законодательства Казахстана и России является то, что эти два государства совместно с Республикой Беларусь являются локомотивами строительства ЕврАзЭС, но данный процесс не будет эффективным без сближения и унификации правовых систем указанных государств. Нужно сказать, что законодательство Казахстана и России, имея общую советскую правовую базу очень схоже, но в тоже время имеет и существенные отличия. Обеспечение религиозной безопасности является одной из ключевых задач для Казахстана и России и, по нашему мнению, именно в этой сфере необходима скорейшая выработка единых стандартов правового регулирования.

В первую очередь, обратимся к понятию религиозного экстремизма, которое дает российский и казахстанский законодатель. Как следует из текста ст. 1 ФЗ Российской Федерации «О противодействии экстремистской деятельности», российский законодатель отказался от формулирования четкого и всестороннего определения понятия «экстремистская деятельность». Вместо этого правоприменителю предложен перечень деяний, входящих в объем данного понятия. В соответствии с ч. 1 ст. 1 Ф3 Российской Федерации «О противодействии экстремистской деятельности» экстремистской деятельностью (экстремизмом) является: возбуждение религиозной розни; пропаганда исключительности, превосходства либо неполноценности человека по признаку его религиозной принадлежности или отношения к религии; нарушение прав, свобод и законных интересов человека и гражданина в зависимости от его религиозной принадлежности или отношения к религии; воспрепятствование законной деятельности религиозных объединений, соединенное с насилием либо угрозой его применения; совершение преступлений по мотивам, указанным в пункте «е» части первой статьи 63 Уголовного кодекса Российской Федерации от 13.06.1996 № 63-ФЗ (ред. от 23.07.2013)4; публичные

${ }^{4}$ Собрание законодательства Российской Федерации. 1996. № 25. Ст. 2954. 
призывы к осуществлению указанных деяний либо массовое распространение заведомо экстремистских материалов, а равно их изготовление или хранение в целях массового распространения.

Кроме того религиозным экстремизмом является публичное заведомо ложное обвинение лица, замещающего государственную должность Российской Федерации или государственную должность субъекта Российской Федерации, в совершении им в период исполнения своих должностных обязанностей указанных выше деяний; организация и подготовка указанных деяний, а также подстрекательство к их осуществлению; финансирование описанных деяний либо иное содействие в их организации, подготовке и осуществлении, в том числе путем предоставления учебной, полиграфической и материально-технической базы, телефонной и иных видов связи или оказания информационных услуг.

Важной особенностью, характеризующей понятие религиозного экстремизма, которое дается в Федеральном законе РФ «О противодействии экстремистской деятельности» является то, что в него включаются все преступные деяния, запрещенные под страхом уголовной ответственности УК РФ, содержащие в качестве квалифицирующего признака совершение преступления по мотивам религиозной ненависти или вражды. Это следующие составы: п. «Л», ч. 2, ст. 105 «Убийство»; п. «е», ч. 2, ст. 111 «Умышленное причинение тяжкого вреда здоровью»; п. «е», ч. 2, ст. 112 «Умышленное причинение средней тяжести вреда здоровью»; п. «б», ч. 2, ст. 115 «Умышленное причинение легкого вреда здоровью»; п. «б», ч. 2, ст. 116 «Побои»; П. «з», ч. 2, ст. 117 «Истязание»; ч. 2, ст. 119 «Угроза убийством или причинением тяжкого вреда здоровью»; п. «б», ч. 1, ст. 213 «Хулиганство»; ч. 2, ст. 214 «Вандализм»; п. «б», ч. 2, ст. 244 «Надругательство над телами умерших и местами их захоронения»; ст. 357 «Геноцид».

Таким образом, понятие экстремизма в российском законодательстве шире перечня экстремистских деяний, предусмотренных УК РФ. Кроме того, список экстремистских деяний согласно законодательству России не подлежит произвольному расширению со стороны правоприменителя. С одной стороны, данный подход хорош тем, что позволяет отнести конкретные действия к экстремизму, «не подгоняя» то или иное деяние к конкретным нормам УК. С другой стороны, ограниченность перечня составов преступлений может привести к ситуации, когда фактически в нем может отсутствовать описание деяний, которые по своей сути являются экстремистскими, но в данном перечне отсутствуют. Думается, что строя перечень экстремистских деяний российский законодатель руководствовался следующими соображениями.

Во-первых, такой метод соответствует требованиям юридической техники, согласно которым «четкие юридические определения должны даваться всем терминам, имеющим решающее значение для правового регулирования» ${ }^{5}$. Во-вторых, четкое указание в законе перечня деяний не допускает расширительного толкования религиозного экстремизма и применения аналогии закона, которая запрещена как нормами Уголовного Кодекса РФ, так и УК Республики Казахстан.

Несколько по другому пути при определении понятия религиозного экстремизма пошел казахстанский законодатель. Часть 5 ст. 1 Закона РК «О противодействии экстремизму» прямо устанавливает, что религиозным экстремизмом является разжигание религиозной вражды или розни, в том числе связанной с насилием или призывами к насилию, а также применение любой религиозной практики, вызывающей угрозу безопасности, жизни, здоровью, нравственности или правам и свободам граждан.

Как видим, круг деяний, которые можно отнести к религиозному экстремизму в законодательстве Казахстана достаточно узок. Но казахстанское законодательство в отличие от российского содержит очень важную на наш взгляд норму, согласно которой религиозным экстремизмом является любая религиозной практики, вызывающая угрозу безопасности, жизни, здоровью, нравственности или правам и свободам граждан. Благодаря этой норме казахстанский правоприменитель располагает правовыми средствами для противодействия достаточно специфическим деяниям, которые могут нести потенциальную опасность для человека. В частности, нормы казахстанского законодательства позволяют ограничивать деятельность многочисленных целителей и экстрасенсов, которая на наш взгляд является экстремистской.

Дело в том, что подавляющее большинство целителей объявляют себя приверженцами какой-либо религии, которая является ключевым фактором их деятельности. Это может быть любая религия. Например, врачеванием могут заниматься последователи Порфирия Иванова, исповедующие культ солнца и сил природы. Практика лечения некоторых заболеваний по методу Порфирия Иванова, в частности, обливание

${ }_{5}^{5}$ Язык закона. М., 1990. С. 129. 


\section{Политика и общество 12 (108) • 2013}

холодной водой в зимний период времени, может привести к серьезным осложнениям многих заболеваний. Но если учитывать, что «врачеватели», как правило, берутся за излечение любых заболеваний, в том числе онкологических, то можно с уверенностью говорить о серьезной опасности такой деятельности для их клиентов. Даже сама по себе попытка справиться с заболеванием (даже простудой) не прибегая к квалифицированной врачебной помощи, несет в себе потенциальную опасность для человека и гражданина.

Религиозная основа присутствует и в практике большинства экстрасенсов ${ }^{6}$. Достаточно часто можно встретить экстрасенсов заявляющих, что они вообще не верят в Бога и используют при врачевании и других манипуляциях некую космическую энергию. Но при детальном исследовании зачастую оказывается, что «получают» они эту энергию от неких потусторонних сил. Существуют особые обряды, позволяющие «правильно» взаимодействовать с этими силами, что уже может указывать на религиозную основу такой деятельности. Кроме того, нужно помнить, что отрицание Бога не всегда является доказательством отсутствия в практике конкретного лица религиозной основы, например, в буддизме вообще отсутствует понятие Бога, что не мешает ему быть одной из мировых религий.

Таким образом, деятельность многих целителей на территории Республики Казахстан возможно рассматривать как экстремистскую поскольку она будучи религиозной несет в себе угрозу безопасности, здоровью, жизни, а также нравственности человека и гражданина. Но законодательство Республики Казахстан не предусматривает никакой ответственности за осуществления такого рода экстремистской деятельности отдельным лицом.

Благодаря определению любой религиозной практики, вызывающей угрозу безопасности, жизни, здоровью, нравственности или правам и свободам граждан в Республике Казахстан как экстремистской невозможно создание учебных заведений по подготовке целителей и экстрасенсов. Деятельность по созданию таких учебных заведений можно квалифицировать по двум

\footnotetext{
${ }^{6}$ Нужно отметить, что провести четкую границу между целителями, колдунами, магами и экстрасенсами практически невозможно. Все они заимствуют отдельные методы «работы» друг у друга. Например, экстрасенс использующий в своей деятельности «космическую энергетику» может применять заговоры и наоборот.
}

статьям Уголовного Кодекса Республики Казахстан ${ }^{7}$ : ст. 233-1 «Пропаганда терроризма либо экстремизма или публичные призывы к совершению акта терроризма» и (или) ст. 233-4 «Вербовка или подготовка либо вооружение лиц в целях организации террористической либо экстремистской деятельности». В России же на данный момента не существует аналогичных правовых средств противодействия данному явлению.

Российский законодатель не рассматривает религиозную практику, вызывающую угрозу безопасности, жизни, здоровью, нравственности или правам и свободам граждан и осуществляемую физическим лицом вне рамок какого-либо объединения как экстремистскую, что мы считаем серьезным упущением. Вследствие такого законодательного пробела в России процветает различного рода целительство и учебные заведения по подготовке врачевателей и экстрасенсов. В соответствии с этим мы считаем необходимым в определение религиозного экстремизма, содержащееся в ст. 1 ФЗ Российской Федерации «О противодействии экстремистской деятельности» включить любую религиозную практику, вызывающую угрозу безопасности, жизни, здоровью, нравственности и правам человека и гражданина. При этом важно в качестве предмета экстремистского деяния обозначить не только гражданина, но и человека, так как государство должно защищать от противоправных посягательств не только своих граждан, но и любое другое физическое лицо, независимо от его гражданства.

Кроме того, необходимо установить за такие деяния уголовную ответственность и дополнить Уголовные кодексы России и Казахстана соответствующими составами, предусматривающими ответственность за любую религиозную практику, вызывающую угрозу безопасности, жизни, здоровью, нравственности или правам человека и гражданина.

Продолжая наше исследование, необходимо заострить внимание еще на одной проблеме правового противодействия религиозному экстремизму. Российское законодательство содержит ст. 280 УК «Публичные призывы к осуществлению экстремистской деятельности». В свою очередь, на пресечение такой деятельности направлена ст. 164 УК РК «Возбуждение социальной, национальной, родовой, расовой или религиозной вражды», а также ст. 233-1 «Пропаганда

\footnotetext{
7 Уголовный кодекс Республики Казахстан от 16.07.1997 N 167-I (ред. от 04.07.2013) // «Ведомости Парламента». 1997. № 15. Ст. 211.
} 
терроризма либо экстремизма или публичные призывы к совершению акта терроризма». Указанные статьи российского и казахстанского законодательства содержат запрет на возбуждение религиозной ненависти и вражды. Но здесь мы сталкиваемся с проблемой терминологического характера. Ни российское, ни казахстанское законодательство не содержат четкого определения того, что понимается под религиозной ненавистью, рознью или враждой. При этом данные термины содержатся в Основных законах обоих государств. Часть 3 ст. 5 Конституции Республики Казахстан от (принята референдумом 30.08.1995 года) ${ }^{8}$ содержит запрет на разжигание религиозной розни. Часть 5 ст. 13 Конституции Российской Федерации (принята всенародным голосованием 12.12.1993) 9 содержит аналогичный запрет, а в соответствии с ч. 2 ст. 29 не допускаются пропаганда или агитация, возбуждающие религиозную ненависть и вражду. Сложность в данном случае заключается в том, что правоприменителю необходимо четко различать, что является возбуждением религиозной ненависти и вражды, а что допустимой проповедью. Последователи традиционных религий имеют обязанность проповедовать свою религию, что невозможно без богословского обоснования ее основ. Но такая проповедь, независимо от тона и от того как она произнесена публично, или в личной беседе может вызвать у некоторых людей раздражение, или даже ненависть. Следствием этого может стать обвинение данного человека в экстремизме, хотя он ни в коей мере не желал разжигания религиозной ненависти или вражды, а только выполнял свой долг верующего человека, озвучивая свою религиозную позицию. Чтобы не допустить такой ситуации, правоприменитель должен четко знать, что понимается под религиозной ненавистью, рознью или враждой. Соответствующими дефинициями могут быть дополнены Федеральный закон РФ «О противодействии экстремистской деятельности» и Закон РК «О противодействии экстремизму».

Но далеко не все проповедники и миссионеры ограничиваются богословским изложением сути своей религии и приемами сравнительного религиоведения. В последние десятилетия существенной проблемой как для российского, так и для казахстанского общества стал прозелитизм, который, по нашему мнению, необ-

\footnotetext{
${ }^{8}$ Ведомости Парламента Республики Казахстан. 1996. № 4. Ст. 217.

${ }^{9}$ С 3 РФ. 2009. № 4. Ст. 445.
}

ходимо относить к религиозному экстремизму. Данное явление получило достаточно большое распространение на территории России и Казахстана.

Определение прозелитизма представляется достаточно серьезной научной проблемой. Конституционный Суд Российской Федерации в своем Постановлении от 23 ноября 1999 г. № 16-П 10 «По делу о проверке конституционности абзацев третьего и четвертого пункта 3 статьи 27 Федерального закона от 26 сентября 1997 года «О свободе совести и о религиозных объединениях» в связи с жалобами Религиозного общества Свидетелей Иеговы в городе Ярославле и религиозного объединения «Христианская церковь Прославления» отметил, что «Государство вправе предусмотреть определенные преграды, с тем чтобы не предоставлять статус религиозной организации автоматически, не допускать легализации сект, нарушающих права человека и совершающих незаконные и преступные деяния, а также воспрепятствовать миссионерской деятельности (в том числе в связи с проблемой прозелитизма), если она несовместима с уважением к свободе мысли, совести и религии других и к иным конституционным правам и свободам, а именно сопровождается предложением материальных или социальных выгод с целью вербовки новых членов в церковь, неправомерным воздействием на людей, находящихся в нужде или в бедственном положении, психологическим давлением или угрозой применения насилия и т.п.».

Таким образом, Конституционный Суд РФ рассматривает прозелитизм как определенную проблему для общества и связывает его с недобросовестной миссионерской деятельностью. Далее в данном Постановлении Конституционный Суд РФ отмечает, что его позиция относительно потенциально опасной для общества миссионерской деятельности согласуется с рядом международных документов, в частности, с «Конвенцией о защите прав человека и основных свобод» (заключена в г. Риме 4 ноября 1950 г.) $)^{11}$, а также с позицией Европейского суда по правам человека. Последний, комментируя ст. 9 указанной конвенции, отмечает, что она не предполагает защиту недопустимых проявлений прозелитизма - предложения материальных выгод или оказания недопустимого давления (в том числе с использованием

\footnotetext{
${ }^{10}$ СЗ РФ. 1999. № 51. Ст. 6363.

${ }^{11}$ С3 РФ. 2001. № 2. СТ. 163.
} 


\section{Политика и общество $12(108) \cdot 2013$}

служебного положения) с целью привлечения в церковь новых членов ${ }^{12}$.

Такую позицию ЕСПЧ поддерживает в деле «Коккинакис против Греции», и определяет прозелитизм, как деятельность выражающаяся в предложении материальных или социальных выгод с целью привлечения новых членов в церковь, оказании ненадлежащего давления на людей, пребывающих в страдании или нужде, или даже применении насилия или промывания мозгов ${ }^{13}$.

Отталкиваясь от вышеизложенного, мы считаем целесообразным определить прозелитизм как деятельность религиозных объединений и отдельных граждан, которая несовместима с уважением к свободе мысли, совести и религии других и к иным конституционным правам, а именно сопровождается предложением материальных или социальных выгод с целью вербовки новых членов в свою церковь, неправомерным воздействием на людей, находящихся в нужде или в бедственном положении, психологическим давлением или угрозой применения насилия.

В качестве примера прозелитизма можно рассматривать деятельность ваххабитских объединений в России и бывших республиках СССР. В настоящее время, в пенитенциарной системе России и Казахстана идет формирование ваххабитской иерархии, которая успешно конкурирует с неформальной (воровской) иерархией, результатом чего стало массовое принятие заключенными ислама радикального толка. Принятие ваххабизма автоматически обеспечивает заключенному защиту и покровительство со стороны ваххабитской ячейки и значительно облегчает выживание в преступной среде. Здесь с целью привлечения новых адептов эксплуатируется человеческий страх, что, по нашему мнению, является прозелитизмом ${ }^{14}$.

\footnotetext{
${ }^{12}$ Стандарты Совета Европы в области прав человека применительно к положениям Конституции Российской Федерации: Избранные права. М., 2002. С. 245.

${ }^{13}$ Цит. по: Постановление ЕСПЧ от 10.06.2010 «Дело «Свидетели Иеговы» в Москве и другие (Jehovah's Witnesses of Moscow and others) против Российской Федерации» (жалоба № 302/02). По делу обжалуется нарушение права на свободу вероисповедания, выражения своего мнения и объединения. По делу нарушены требования статей $9,11,14$, пункта 1 статьи 6 Конвенции о защите прав человека и основных свобод // «Российская хроника Европейского Суда». 2011. № 2.

${ }^{14}$ См.: Ваххабиты вербуют сторонников в российских тюрьмах / Информационное агентство «REGNUM». 2012. URL: http://russia. ru/news/society/2012/12/3/5353.html (дата обращения: 9.02.13).
}

Также к прозелитизму мы относим предложения со стороны религиозных объединений деструктивной направленности «излечения» от наркотической или алкогольной зависимости. В данном случае потенциальный адепт или его родственники идут на принятие нового религиозного мировоззрения, надеясь на избавление от заболевания, то есть эксплуатируется их бедственное положение ${ }^{15}$.

Необходимо отметить, что некоторые современные государства к проблеме прозелитизма относятся очень серьезно и иногда ограничивают его на уровне Основного закона. Например, согласно ч. 2 ст. 13 Конституции Греции от 11 июня 1975 г. ${ }^{16}$ «... Прозелитизм запрещается».

Другие государства противодействуют прозелитизму на уровне уголовного законодательства. В частности, Уголовный кодекс Республики Узбекистан от 22.09.1994 г. № 2012-ХІІ (ред. от 07.10.2013) ${ }^{17}$ содержит ст. 216-2 «Нарушение законодательства о религиозных организациях», согласно ч. 2 которой «Обращение верующих одних конфессий в другие (прозелитизм) и другая миссионерская деятельность после применения административного взыскания за такие же действия» образует состав преступления.

Соответственно, мы считаем необходимым в законодательном порядке признать прозелитизм экстремистской деятельностью и в этой связи полагаем дополнить понятием прозелитизма Федеральный закон РФ «О противодействии экстремистской деятельности» и Закон РК «О противодействии экстремизму». Кроме того, необходимо рассмотреть вопрос об установлении за такие действия меры юридической ответственности, вплоть до уголовной. Эти меры, несомненно, послужат укреплению религиозной безопасности России и Казахстана.

Таким образом, в данной статье мы рассмотрели основные нормы законодательства Российской Федерации и Республики Казахстан, направленные на обеспечение религиозной безопасности. Нами были

\footnotetext{
15 См.: Доброе дело с подвохом. Общество // Советская Сибирь. Новосибирская областная газета. № 166 (26789). 08.09.2012. URL: http://www.sovsibir.ru/index.php?dn=news\& to $=$ art\&ye $=2012 \& \mathrm{id}=4682$ (дата обращения: 09.02.13).

${ }^{16}$ Конституция Греции. Вступила в силу 11 июня 1975 г. / constitutions.ru 21.12.2008. URL: http://constitutions.ru/archives/249 (дата обращения:16.02.13).

17 Ведомости Верховного Совета Республики Узбекистан.
} 1995. № 1. 
выявлены слабые и сильные стороны правового регулирования в данной сфере жизни российского и казахстанского общества. По нашему мнению, существует значительный потенциал по совершенствованию соответствующего законодательства двух странстратегических партнеров, отличающихся близостью правовых систем и менталитета населения.

\section{Библиография:}

1. Конституция Российской Федерации (принята всенародным голосованием 12.12.1993) (с учётом поправок, внесённых Законами РФ о поправках к Конституции РФ от 30.12.2008 № 6-ФКЗ, от 30.12.2008 № 7-ФКЗ) // Собрание законодательства Российской Федерации. 2009. № 4. Ст. 445.

2. Конвенции о защите прав человека и основных свобод (заключена в г. Риме 4 ноября 1950 г.) // Собрание законодательства Российской Федерации. 2001. № 2. Ст. 163.

3. Уголовный кодекс Российской Федерации от 13.06.1996 № 63-Ф3 (ред. от 23.07.2013) // Собрание законодательства Российской Федерации. 1996. № 25. Ст. 2954.

4. Федерального закона Российской Федерации «О противодействии экстремистской деятельности» от 25 июля 2002 г. № 114-Ф3 (ред. от 02.07.2013) // Собрание законодательства Российской Федерации. 2002. № 30. Ст. 3031.

5. Постановление Конституционного Суда РФ «По делу о проверке конституционности абзацев третьего и четвертого пункта 3 статьи 27 Федерального закона от 26 сентября 1997 г. «О свободе совести и о религиозных объединениях» в связи с жалобами Религиозного общества Свидетелей Иеговы в городе Ярославле и религиозного объединения «Христианская церковь Прославления» от 23.11.1999 № 16-П // Собрание законодательства Российской Федерации. 1999. № 51. Ст. 6363.

6. Конституции Республики Казахстан (принята референдумом 30.08.1995 года) // Ведомости Парламента Республики Казахстан. 1996. № 4. Ст. 217.

7. Уголовный кодекс Республики Казахстан от 16.07.1997 N 167-I (ред. от 04.07.2013) // «Ведомости Парламента». 1997. № 15. Ст. 211.

8. Закона Республики Казахстан «О противодействии экстремизму» от 18 февраля 2005 года
№ 31-III (ред. от 13.02.2012) // «Казахстанская правда» от 26 февраля 2005 г. № 45-46 (2465524656).

9. Конституция Греции. Вступила в силу 11 июня 1975 г. / constitutions.ru 21.12.2008. URL: http:// constitutions.ru/archives/249 (дата обращения:16.02.13).

10. Уголовный кодекс Республики Узбекистан от 22.09.1994 г. № 2012-ХІІ (ред. от 07.10.2013) // Ведомости Верховного Совета Республики Узбекистан. 1995. № 1.

11. Стандарты Совета Европы в области прав человека применительно к положениям Конституции Российской Федерации: Избранные права. М.: Институт права и публичной политики, 2002. 606 с.

12. Постановление ЕСПЧ от 10.06.2010 «Дело «Свидетели Иеговы» в Москве и другие (Jehovah's Witnesses of Moscow and others) против Российской Федерации» (жалоба № 302/02). По делу обжалуется нарушение права на свободу вероисповедания, выражения своего мнения и объединения. По делу нарушены требования статей 9, 11,14 , пункта 1 статьи 6 Конвенции о защите прав человека и основных свобод // «Российская хроника Европейского Суда». 2011. № 2.

13. Ваххабиты вербуют сторонников в российских тюрьмах / Информационное агентство «REGNUM». 2012. URL: http://russia.ru/news/ society/2012/12/3/5353.html (дата обращения: 9.02.13).

14. Доброе дело с подвохом. Общество // Советская Сибирь. Новосибирская областная газета. № 166 (26789). 08.09.2012. URL: http://www.sovsibir.ru/ index.php?dn $=$ news \& to $=\operatorname{art} \& y e=2012 \& \mathrm{id}=4682$ (дата обращения: 09.02.13).

15. Тарасевич И.А. Религиозная безопасность Российской Федерации. Тюмень: Издательство Тюменского государственного университета, 2013. 288 c.

16. Язык закона / Под ред. А.С. Пиголкина. М.: Юрид. лит., 1990. 192 с.

\section{References (transliteration):}

1. Tarasevich I.A. Religioznaya bezopasnost' Rossiiskoi Federatsii. Tyumen': Izdatel'stvo Tyumenskogo gosudarstvennogo universiteta, 2013. 288 s. 